\title{
Mineral elements in some wild mushrooms
}

\section{RAUNI OHTONEN}

OHTONEN, R. 1978: Mineral elements in some wild mushrooms. - Karstenia 18 (suppl.).

Major and trace mineral elements were measured from three species of mushrooms, Lactarius rufus, Suillus variegatus and Russula paludosa and from the humus at their growing sites. The elements measured were $\mathrm{K}, \mathrm{Na}, \mathrm{Ca}, \mathrm{Mg}, \mathrm{Mn}, \mathrm{Fe}, \mathrm{Cu}$ and $\mathrm{Zn}$. A correlation was found between the $\mathrm{Mg}$ content of the humus and the mushrooms. The difference between the stipe and the pileus was very clear. The Fe content of $S$. variegatus was tens of times higher compared with that of the other species. The positive correlation between $\mathrm{Cu}$ and $\mathrm{Zn}$ was highly significant in the three mushroom species studied.

R. Ohtonen, Department of Botany, University of Oulu, SF-90100 Oulu 10, Finland.

\section{Introduction}

The aim of the present study, which is still in process, is threefold: 1) to determine the concentration of certain major and trace elements in mushrooms growing in unfertilized heath forests; 2) to measure the possible differences in the element contents of the pileus and the stipe; 3) to investigate the possible correlation between the element concentrations in the mushrooms and in the soil.

\section{Material and methods}

The species under study are Lactarius rufus, suilius variegatus and Russula paludosa. Material was collected from 4 different heath forests in Northern Finland close to oulu $\left(65^{\circ} \mathrm{N}\right)$. The types of forests were: $\mathrm{A}=$ Cladonia-type (CIT), B = Empetrum-Vaccinium-type (EVT), $C=$ marshy EVT, $D=$ Vaccinium-type (VT). The mushroom samples were wet-digested (25 ml $\mathrm{HNO}_{3}$ and $5 \mathrm{ml} \mathrm{HClO}_{4}$ ). From the solution $\mathrm{K}, \mathrm{Na}, \mathrm{Ca}, \mathrm{Mg}$, $\mathrm{Mn}, \mathrm{Fe}, \mathrm{Cu}$ and $\mathrm{Zn}$ were measured by using a Perkin Elmer atomic absorption spectrophotometer. It seems that this method is not suited to the alkali metals, because a large portion of potassium and sodium precipitates and crystallizes.

From each growing site, ten samples were collected from the humus ( $\mathrm{Hl}$ from the upper level and $\mathrm{H} 2$ from the lower level of the humus). These samples were extracted with ammonium acetate ( $\mathrm{pH} 4.65)$.

\section{Results and discussion}

The method used resulted in contents of $\mathrm{K}$ and $\mathrm{Na}$ lower than those reported by other authors, which are $2000-5370 \mathrm{mg} / 100 \mathrm{~g}$ for K (Souci et al. 1969, Isotalo 1971, Kreula et al. 1976) and $14-700 \mathrm{mg} / 100 \mathrm{~g}$ for $\mathrm{Na}$

(Souci et al. 1969, Kreula et al. 1976).

The content of $\mathrm{Ca}$ was about the same in the different species of mushrooms (14-42 mg/100 g in me- dium). The contents were lowest in $R$. paludosa (Fig. 1 ). The stipes of $L$, rufus and $S$, variagatus contained about twice the amount of $\mathrm{Ca}$ found in the pilei of the same species. No such difference was observable in $R$. paludosa. There was a significant difference $(P<0.05)$ in $L$. rufus collected from two different growing sites ( $\mathrm{A}$ and $\mathrm{C}$ ). The content of $\mathrm{Ca}$ in mushrooms can vary remarcably, from 6.6 to several hundreds of $\mathrm{mg} / 100 \mathrm{~g}$ (Hinneri 1975).

The mean content of $\mathrm{Mg}$ in the mushrooms studied was $24-130 \mathrm{mg} / 100 \mathrm{~g}$. The contents were lowest in $L$. rufus (Fig. 1). The Mg content of the stipe is about half of that of the pileus in the three species. The $\mathrm{Mg}$ content reported in the literature varies within 30-273 $\mathrm{mg} / 100 \mathrm{~g}$ (Hinneri 1975). Soil samples showed that the $\mathrm{Mg}$ content of the humus in CIT (A) is significantly lower than that in forests of other types. This could also be noted in $L$. rufus and in $S$. variegatus. $L$. rufus displayed a significant difference between the growing sites $A$ and $C(P<0.01)$. In the same way, there was a significant difference in $S$. variegatus between the growing sites $A$ and $B(P<0.05)$, as well as $A$ and $D(P<0.05)$ (Fig. 1).

The Mn content was at its lowest in the pileus of $s$. variegatus, $0.6-1.3 \mathrm{mg} / 100 \mathrm{~g}$, on an average. The content of $\mathrm{Mn}$ in the stipe was remarkably higher, $2.3-3.3 \mathrm{mg} / 100 \mathrm{~g}$ (Fig. 1). In contrast to that, $R$. paludosa had a Mn content of the stipe lower than that of the pileus. L. rufus had a significant difference between the stipe and the pileus only in CIT (A).

The Mn content varied in the mushrooms studied, being $0.6-4.7 \mathrm{mg} / 100 \mathrm{~g}$, on an average, which is in agreement with the values reported in the literature (Hinneri 1975).

The amount of $\mathrm{Fe}$ was very high in S.variegatus, 140-280 $\mathrm{mg} / 100 \mathrm{~g}$, on an average, while L. rufus and 
Fig. 1. Mineral elements in different mushroom species ( $\mathrm{mg} / 100 \mathrm{~g}$ ) and in the soil samples $(\mathrm{mg} / \mathrm{l}) . A=$ ClT, $B=E V T, C=$ marshy EVT, $D=V T$. The checked columns = the pileus of mushrooms; the white columns $=$ the feet of mushrooms. In the soil samples the left column $=H$ l (the upper level of the humus); the right column $=\mathrm{H} 2$ (the lower level of the humus).
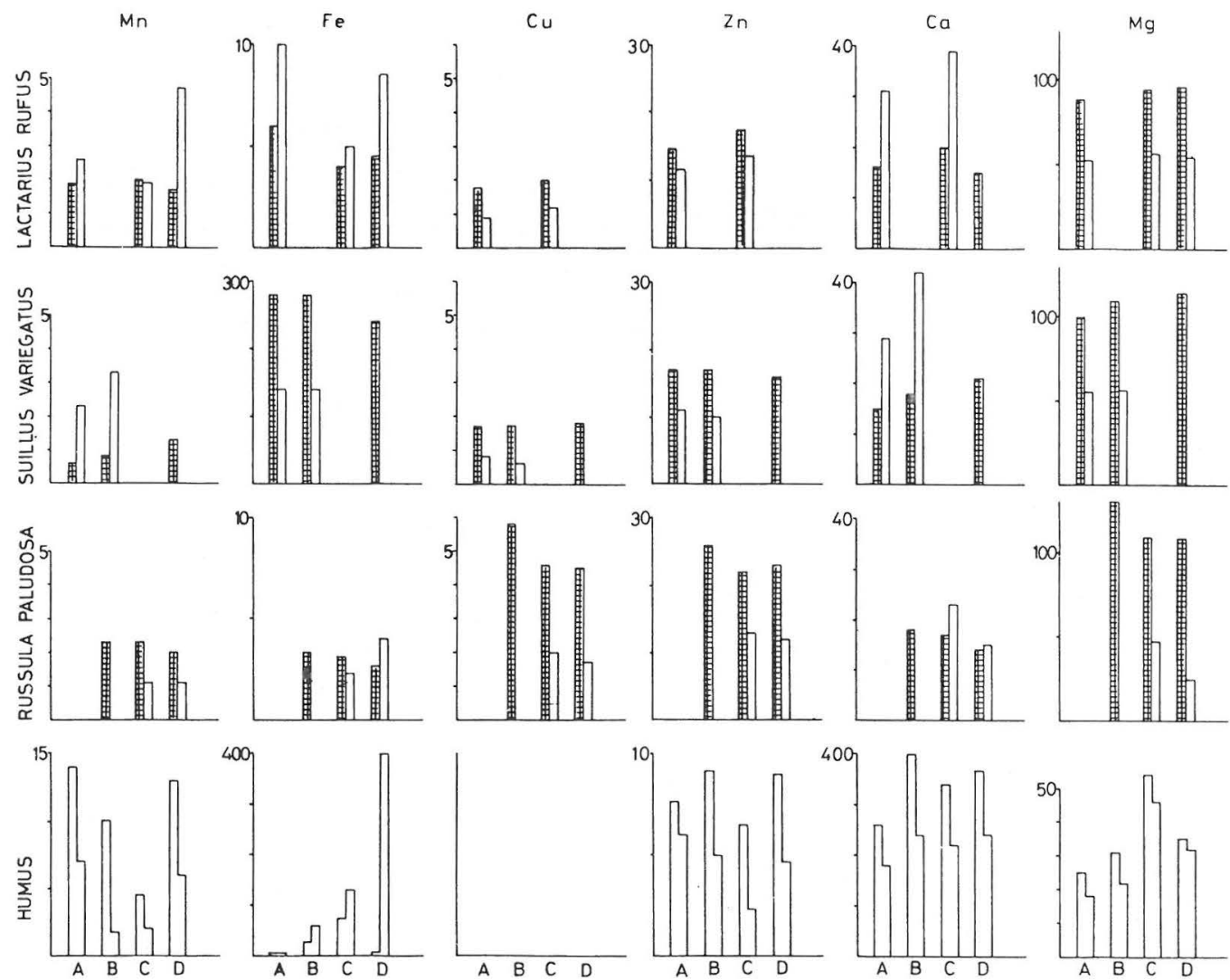

$R$. paludosa had an average content of $\mathrm{Fe}$ of 2.3-9.6 $\mathrm{mg} / 100 \mathrm{~g}$ (Fig. 1). The Fe content of the stipe of L. rufus was higher than that of the pileus, while $S$. variegatus had the highest $\mathrm{Fe}$ content in the pileus. $R$. paludosa had no significant difference between the stipe and the pileus.

other authors have also observed considerable variation in the $\mathrm{Fe}$ content of mushrooms, 3.1-140 mg/ $100 \mathrm{~g}$ (Hinneri 1975), the most common level being $8-10 \mathrm{mg} / 100 \mathrm{~g}$. This is about the same as the findings for $L$. rufus and $R$. paludosa in this study, whereas the $F e$ content in $S$. variegatus is remarkably high compared with other mushrooms.

The $\mathrm{Cu}$ contents of $L$, rufus and $S$. variegatus were very similar, being $0.6-2.0 \mathrm{mg} / 100 \mathrm{~g}$, on an average (Fig. 1). The Cu content in $R$. paludosa was significantly higher $(\mathrm{P}<0.001)$ than that in the other two mushroom species, $1.7-5.8 \mathrm{mg} / 100 \mathrm{~g}$. All the three species had more $\mathrm{Cu}$ in the pileus than in the stipe. The values of $\mathrm{Cu}$ reported in the literature are $0.3-29 \mathrm{mg} / 100 \mathrm{~g}$ (Hinneri 1975), but the common level is $2-6 \mathrm{mg} / 100 \mathrm{~g}$, which is in agreement with the presext findings.

The $\mathrm{Cu}$ content of the humus was not revealed by the method used, or it was quite low.

The $\mathrm{Zn}$ content in the mushrooms studied was about 6 times higher than that of $\mathrm{Cu}, 10-26 \mathrm{mg} / 100 \mathrm{~g}$ (Fig. 1). The highest amount of $\mathrm{Zn}$ reported in the literature is $120 \mathrm{mg} / 100 \mathrm{~g}$ (Hinneri 1975), but the contents of $\mathrm{Zn}$ are commonly lower thar $50 \mathrm{mg} / 100 \mathrm{~g}$. The content of $\mathrm{Zn}$ was higher in the pileus than in the stipe. The $\mathrm{Zn}$ content of $R$. paludosa was significantly higher $(P<0.01)$ than that of L.rufus and $S$. variegatus. The positive correlation between 
Fig. 2. Correlation between $\mathrm{Cu}$ and $\mathrm{Zn}$ contents of the pileus $(\cdot)$ and the stipe $(\Delta)$. I = Lactarius rufus, II = Suillus variegatus, III = Russula pazudos $\alpha$.
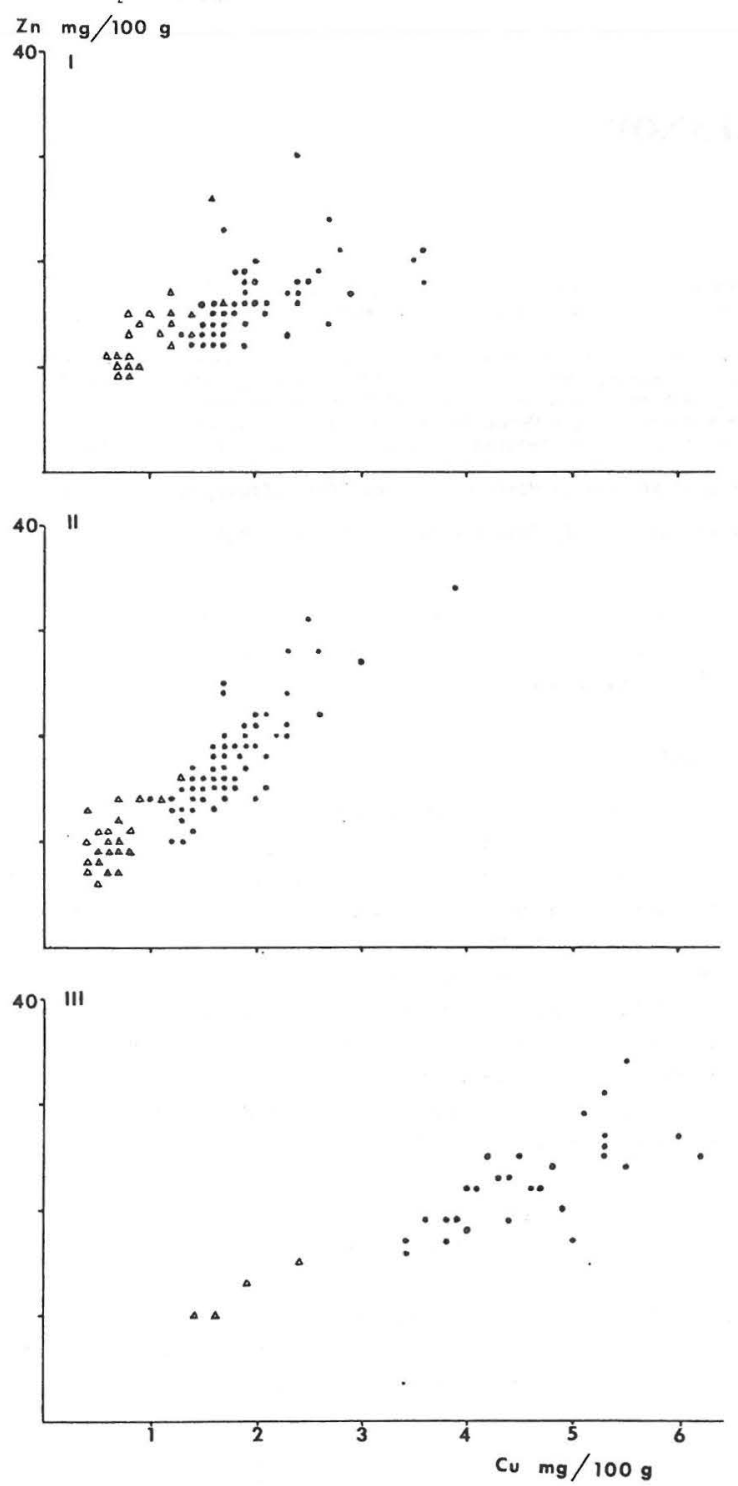

$\mathrm{Cu}$ and $\mathrm{Zn}$ is highly significant in the three mushroom species (Fig. 2). The correlation coefficient is 0.75 for $L$. rufus, 0.89 for $S$. variegatus and 0.86 for R. parudosa.

It can be assumed from the $\mathrm{Cu}$ and $\mathrm{Zn}$ contents in the soil studied that the mushrooms have absorbed all the available $\mathrm{Cu}$ and $\mathrm{Zn}$. In contrast, there seems to be more $\mathrm{Mn}$ in the soil than can be used, and the mushrooms have absorbed only the optimal amount, which is not more than the amount of $\mathrm{Cu}$. The $\mathrm{Mg}$ contents were also relatively high in the mushrooms compared with those of the soil samples, and it is possible that the mushrooms have absorbed $\mathrm{Mg}$, similarly to $\mathrm{Cu}$ and $\mathrm{Zn}$, as much as they have been able to extract from the soil. This can explain the difference in the data obtained for $L$. rufus and $S$. variegatus collected from different growing sites, where the contents of soil samples varied.

\section{References}

Hinneri, S. 1975: Mineral elements of macrofungi in oak-rich forests on Lenholm Island, inner archipelago of SW Finland. - Ann. Bot. Fennici 12: $135-140$.

Isotalo, A. 1971: Porojen luonnonvaraisten rehukasvien ravintoarvosta. - Lapin tutkimusseuran vuosikirja 12: 28-45.

Kreula, M., Saarivirta, M.-\& Karanko, S.L. 1976: On the composition of nutrients in wild and cultivated mushrooms. - Karstenia 16: 10-14.

Souci, S.W., Fachmann, W. \& Kraut, H. 1969: Die Zusammensetzung der Lebensmittel. II. - Wissenschaftliche Verlagsgesellschaft M.B.H., Stuttgart. 